\title{
Change in hepatitis $C$ virus positivity among needle-stick injury source patients: a 10-year experience in a Japanese tertiary hospital
}

Kazuya Okushin ${ }^{1,2}$, Rie Suzuki ${ }^{1}$, Takeya Tsutsumi ${ }^{3}$, Koh Okamoto ${ }^{4}$, Kazuhiko Ikeuchi, ${ }^{3,4}$, Akira Kado ${ }^{2}$, Chihiro Minatsuki ${ }^{1,2}$, Yuka Minami-Kobayashi ${ }^{1,2}$, Nobuhiko Satoh ${ }^{1}$, Mahoko Ikeda ${ }^{1,4}$, Sohei Harada ${ }^{1,4}$, Kenichiro Enooku ${ }^{2}$, Hidetaka Fujinaga ${ }^{2}$, Hiroshi Yotsuyanagi ${ }^{3}$, Kazuhiko Koike ${ }^{2}$ and Kyoji Moriya ${ }^{1,4^{*}}$

\begin{abstract}
Background: As a blood-borne pathogen, hepatitis C virus (HCV) has long been a major threat associated with needle-stick injuries (NSIs) mainly because no vaccine is available for HCV. Following an NSI, we usually test the source patient for HCV antibody (HCV-Ab). Since HCV-Ab positivity does not necessarily indicate current infection, HCV RNA is further examined in patients positive for HCV-Ab. Direct-acting antivirals (DAAs) have enabled us to treat most HCV-infected patients; therefore, we speculate that the rate of HCV RNA positivity among HCV-Abpositive patients decreased after the emergence of DAAs. This cross-sectional study was performed to investigate the change in the actual HCV RNA positivity rate in source patients before and after the interferon (IFN)-free DAA era.
\end{abstract}

Methods: This was a cross-sectional study of NSI source patients at a tertiary academic hospital in Japan from 2009 to 2019. IFN-free DAA regimens were first introduced in Japan in 2014. Accordingly, we compared HCV status of NSI source patients that occurred between 2009 and 2014 (the era before IFN-free DAAs) with those that occurred between 2015 and 2019 (the era of IFN-free DAAs) in a tertiary care hospital in Japan.

\footnotetext{
* Correspondence: moriyakyojl0720@gmail.com

1 Department of Infection Control and Prevention, Graduate School of

Medicine, The University of Tokyo, 7-3-1 Hongo, Bunkyo-ku, Tokyo 113-8655,

Japan

${ }^{4}$ Department of Infectious Diseases, Graduate School of Medicine, The University of Tokyo, Tokyo, Japan

Full list of author information is available at the end of the article
}

(c) The Author(s). 2021 Open Access This article is licensed under a Creative Commons Attribution 4.0 International License, which permits use, sharing, adaptation, distribution and reproduction in any medium or format, as long as you give appropriate credit to the original author(s) and the source, provide a link to the Creative Commons licence, and indicate if changes were made. The images or other third party material in this article are included in the article's Creative Commons licence, unless indicated otherwise in a credit line to the material. If material is not included in the article's Creative Commons licence and your intended use is not permitted by statutory regulation or exceeds the permitted use, you will need to obtain permission directly from the copyright holder. To view a copy of this licence, visit http://creativecommons.org/licenses/by/4.0/. The Creative Commons Public Domain Dedication waiver (http://creativecommons.org/publicdomain/zero/1.0/) applies to the data made available in this article, unless otherwise stated in a credit line to the data. 
(Continued from previous page)

Results: In total, 1435 NSIs occurred, and 150 HCV-Ab-positive patients were analyzed. The proportion of HCV RNApositive patients significantly changed from 2009 through 2019 ( $p=0.005$, Cochran-Armitage test). Between 2009 and 2014, 102 source patients were HCV-Ab-positive, 78 of whom were also positive for $\mathrm{HCV}$ RNA $(76.5 \%$; 95\%Cl, 67.4-83.6\%). Between 2015 and 2019, 48 patients were HCV-Ab-positive, 23 of whom were also positive for HCV RNA (47.9\%; 95\%Cl, 34.5-61.7\%; $p=0.0007$ compared with 2009-2014). In the era of IFN-free DAAs, 9 of 23 HCV RNA-negative patients (39.1\%) and 2 of 22 HCV RNA-positive patients (9.1\%) were treated with an IFN-free combination of DAAs $(p=0.0351)$. Regarding the departments where NSIs occurred, HCV RNA-negative patients were predominant in departments not related to liver diseases in the era of IFN-free DAAs ( $p=0.0078$, compared with 2009-2014).

Conclusions: Actual HCV RNA positivity in source patients of NSIs decreased after the emergence of IFN-free DAAs. IFN-free DAAs might have contributed to this reduction, and HCV RNA-negative patients were predominant in departments not related to liver diseases in the era of IFN-free DAAs.

Keywords: Needle-stick injury, HCV, HCV antibody, HCV RNA

\section{Introduction}

Healthcare workers (HCWs) are at risk of infection due to needle-stick injuries (NSIs) worldwide [1, 2]. Among the three major blood-borne pathogens transmitted through NSIs, i.e., hepatitis $\mathrm{C}$ virus (HCV), hepatitis $\mathrm{B}$ virus (HBV), and human immunodeficiency virus (HIV), immunization is available for only HBV (4). Moreover, postexposure management has been well established for HIV and HBV [3, 4]. In contrast, no vaccine is available for HCV [5]. Postexposure prophylaxis (PEP) strategies for $\mathrm{HCV}$ using direct-acting antivirals (DAAs) have been reported but are not considered cost-effective [6]. When HCWs suffer NSIs associated with an HCV-positive source patient, they can be only monitored for the development of hepatitis C. Consequently, HCV has long been a major threat in the context of NSIs despite its low rate of transmission (approximately 1.8\%) due to the absence of valid immunization [7, 8].

When an NSI occurs, a source patient is tested for the presence of $\mathrm{HCV}$ antibody ( $\mathrm{HCV}-\mathrm{Ab})$ [7, 9]. A positive $\mathrm{HCV}-\mathrm{Ab}$ result indicates current or previous infection or a false-positive result [10]. The presence of serum $\mathrm{HCV}$ RNA indicates active $\mathrm{HCV}$ infection, and high HCV RNA levels appear to correlate with an increased risk of transmission [11, 12]. Consequently, HCV RNA is detected to confirm the current infection status in positive $\mathrm{HCV}-\mathrm{Ab}$ patients $[7,9]$.

The reported prevalence of $\mathrm{HCV}$ among NSI source patients varies considerably depending on the patient population, geographical location and time period examined. For example, in Japan, the national burden of HCV infection was estimated in 2005. Tanaka et al. reported that $807,903(95 \%$ CI $679,886-974,292)$ of the total population of $127,285,653$ were estimated to be infected with $\mathrm{HCV}$ at a carrier rate of $0.63 \%$ [13]. Furthermore, in Japan, most hepatitis $C$ positive patients are elderly [13] because the illicit intravenous amphetamine abuse during the turmoil period just after World War II is considered as a possible transmission route of HCV [14], in addition to current illegal injection drug use and previous transfusion of contaminated blood products which are common in other countries.

According to the prevalence of $\mathrm{HCV}$ among NSI source patients in Japan, Mitsui et al. reported that 91 patients (57.2\%) were positive for HCV-Ab among 159 NSI source patients, and 81 patients $(89.0 \%)$ were also positive for HCV RNA among $91 \mathrm{HCV}$-Ab-positive patients in 1992 [12]. However, since then, the actual HCV positivity rate among NSI source patients based on HCV RNA analysis has not been reported.

In the last decade, several interferon (IFN)-free DAAs have been developed and widely used for the treatment of chronic HCV infection. As IFN-free DAAs efficiently eliminate $\mathrm{HCV}$ and almost all patients achieve a sustained virological response (SVR) $[15,16]$, we speculated that HCV RNA positivity decreased after the introduction of IFN-free DAAs.

In this cross-sectional study, we retrospectively analyzed the HCV-Ab and HCV RNA statuses of NSI source patients to investigate the change in the HCV RNA positivity rate between the eras before and after the emergence of IFN-free DAAs.

\section{Materials and methods \\ Patients}

We retrospectively analyzed the laboratory data of NSI source patients at The University of Tokyo Hospital (UTH), Tokyo, Japan (1228 beds and approximately 4000 employees) from January 2009 to December 2019. UTH is a tertiary academic hospital that provides general and specialized services, including hepatology and liver transplantation. At UTH, all HCWs are required to report NSIs to the Department of Infection Control and Prevention according to the institutional guideline 
mandate. The reported data include date, site, NSI device, and the source patient's blood-borne pathogen status. NSI cases were identified using the Department of Infection Control and Prevention database. We included all HCW NSI cases with HCV-Ab-positive source patients. We excluded cases with incomplete data, such as cases with incorrect medical record numbers for source patients or NSIs that occurred during forensic autopsy. Only the first NSI was analyzed if the same patient was the source in multiple NSI cases. We further excluded cases whose HCV RNA data were not available.

We manually extracted the following variables from the database and medical records of source patients: date, age, sex, HCV RNA status, HCV-Ab titer, and the department where the NSI occurred. We further extracted source patients' histories of antiviral treatment for HCV prior to the incidence of NSIs. We dichotomized the study period into before interferon (IFN)-free DAAs (December 2014 and earlier) and after IFN-free DAAs (January 2015 and later) because the first IFN-free DAA regimen (daclatasvir hydrochloride and asunaprevir, DCV/ASV) was introduced in September 2014, followed by several IFN-free DAA regimens, such as ledipasvir/sofosbuvir (LDV/SOF), sofosbuvir/ribavirin (SOF/RBV), glecaprevir/pibrentasvir, and sofosbuvir/velpatasvir. Because the prevalence of $\mathrm{HCV}$ infections among patients is greatly dependent on whether they are specifically provided care with liver diseases, we classified the department where the NSI occurred as either a liver disease-related department (LD, approximately 130 beds) or a nonliver disease-related department (non-LD, approximately 1100 beds). The LDs included the Department of Gastroenterology, the Department of Infectious Diseases, and the Hepato-Biliary-Pancreatic Surgery and the Artificial Organ and Transplantation Surgery divisions of the Department of Surgery. All other departments were classified as non-LDs. Of note, 329,390 serum samples were tested for HCV-Abs, and 11,181 (3.4\%) were positive during the study period. In the LDs and non-LDs, 4765 of 37,817 serum samples (12.6\%) and 6416 of 291,573 serum samples (2.2\%) were positive for $\mathrm{HCV}-\mathrm{Ab}$, respectively.

This study was approved by the Ethics Committee of The University of Tokyo (No. 2187) and conformed to the Declaration of Helsinki. Informed consent was obtained from all subjects included in this study using the opt-out informed consent procedure. Namely, on admission, all of the inpatients were provided with a document explaining the policy of The University of Tokyo Hospital on protection of personal information and handling of samples of human origin. Any patients could request for suspension of use, elimination, provision of own personal information. In addition, a document that declares an opt-out policy by which any possible patient could refuse to be included in this study was uploaded on the web page of the The University of Tokyo Hospital.

\section{Testing for HCV-Ab and HCV RNA and the definition of current infection status}

All samples were tested for immunoglobulin G (IgG) antibodies against $\mathrm{HCV}$ using either a chemiluminescent immunoassay (cutoff value, $\geq 1.0 \mathrm{~S} / \mathrm{CO}$ ) or chemiluminescent enzyme immunoassay (cutoff value, $\geq 1.0 \mathrm{~S} / \mathrm{CO}$ ).

In patients with $\mathrm{HCV}$-Ab-positive status, $\mathrm{HCV}$ RNA was analyzed by the Amplicor HCV test (Roche Diagnostics, Tokyo, Japan) or by real-time polymerase chain reaction by the COBAS TaqMan HCV test (Roche Diagnostics, Tokyo, Japan). We defined HCV RNA-positive patients as those with active $\mathrm{HCV}$ infection, including 1) an HCV RNA-positive result obtained at the time of the NSI; 2) an HCV RNA-positive result obtained before the NSI and no history of HCV treatment until the NSI; and 3) an HCV RNA-positive result obtained after the NSI and with no other possible route of HCV infection after the NSI.

\section{Follow up of health care workers after NSIs}

We monitored HCWs after NSIs from HCV-Ab-positive patients as follows. We checked serum titers of $\mathrm{HCV}-\mathrm{Ab}$ and values of liver enzymes of suffered HCWs immediately after the NSI and also after 1 month, 3 months, and 6 months. We also checked the HCV RNA of the HCW at 1 month. If at least one of the titers of HCV-Ab after 1,3 , or 6 months was above the cut-off level and/or the HCV RNA at 1 month was positive, we regarded the NSI as a cause of $\mathrm{HCV}$ transmission.

\section{Statistics}

Data processing and analysis were performed with JMP Pro 15 software (SAS Institute Japan, Tokyo, Japan). Continuous variables were compared using Welch's $t$ test or Wilcoxon's rank-sum test, and categorical variables were compared using Fisher's exact test. The Cochran-Armitage trend test was used to evaluate increasing or decreasing trends. A $p$-value $<0.05$ was considered to indicate statistical significance.

\section{Results}

Between 2009 and 2019, 1435 NSIs occurred. All sources of NSIs were patients, and some patients were sources of multiple NSIs. The number of total NSIs and that per 1000 beds in each year were summarized in Supplementary Table 1. Between January 2009 and December 2014 (the era before IFN-free DAAs) and between January 2015 and December 2019 (the era of IFN-free DAAs), 884 and 551 NSIs occurred, respectively. The overall rate of NSIs in our hospital was lower in the era of IFN-free DAAs than in the era before DAAs (89.7 vs 120.0 NSIs/ 
1000 beds/year; 95\% confidence interval [CI], 81.7 to 97.7 vs 102.3 to $137.5 ; p=0.0106$, Wilcoxon's rank-sum test).

Among all 1435 NSIs, 204 injuries (14.2\%; 95\%CI, 12.5 to $16.1 \%$ ) were associated with HCV-Ab-positive source patients. Of those, 54 cases were excluded (insufficient data, $n=10$; multiple exposures from the same patient, $n=17$; unavailable HCV RNA viral load data, $n=27$ ). The remaining 150 NSIs associated with 150 source patients were analyzed (Fig. 1). Detailed situations of 150 NSIs were as follows: incision or suture, $n=46$; blood collection, $n=36$; percutaneous injection, $n=32$; catheter-related procedure, $n=16$; body fluid or tissue collection, $n=5$; other invasive or surgical procedures, $n=14$; unknown, $n=1$. Among the 150 source patients, 101 patients were HCV RNA-positive, 88 were male, and the mean age was 70.0 years old (Table 1). There was no transmission of $\mathrm{HCV}$ to $\mathrm{HCW}$ during the entire study period.

The proportion of HCV RNA-positive patients significantly changed from 2009 through 2019 (Fig. 2, $p=$ 0.005, Cochran-Armitage test). The proportion of $\mathrm{HCV}$ RNA-positive patients decreased from $65.0 \%$ in 2009 to $37.5 \%$ in 2019. The number of HCV-Ab-positive, HCV RNA-positive, and HCV RNA-negative NSIs in each year were summarized in Supplementary Table 1.

We then compared the source patients in the era before DAAs with those in the era of IFN-free DAAs. In the era before IFN-free DAAs 102 patients were $\mathrm{HCV}$ $\mathrm{Ab}$ positive, and HCV RNA was analyzed. Seventy-eight of the patients were positive for HCV RNA (76.5\%; 95\%CI, 67.4-83.6\%). On the other hand, in the era of IFN-free DAAs, 48 patients were HCV-Ab positive, and HCV RNA was analyzed. Twenty-three of the patients were positive for HCV RNA (47.9\%; 95\%CI, 34.5-61.7\%; $p=0.0007$ compared with 2009-2014) (Table 1).

Age, sex, and department where the NSI occurred were not significantly different between the eras before and after DAAs in the HCV-Ab-positive source patients (Table 1). However, the mean age was significantly higher in HCV RNA-positive patients than in HCV RNA-negative patients in the era before DAAs (Table 2). $\mathrm{HCV}-\mathrm{Ab}$ titers were significantly higher in HCV RNApositive patients than in HCV RNA-negative patients in both eras (Table 2).

In the era before DAAs, the rates of IFN-based therapies were not significantly different between HCV RNApositive and HCV RNA-negative patients (Table 2). In the era of IFN-free DAAs, the rates of IFN-based therapies were also not significantly different between $\mathrm{HCV}$ RNA-positive and HCV RNA-negative patients. On the other hand, IFN-free DAAs therapies were significantly conducted in HCV RNA-negative patients compared with HCV RNA-positive patients. Details of the IFN-free DAAs were as follows: LDV/SOF in two HCV RNAnegative patients and two HCV RNA-positive patients, DCV/ASV in four HCV RNA-negative patients, and SOF/RBV in three HCV RNA-negative patients. There was no patient treated with the combination regimens with interferon and DAAs such as telaprevir or simeprevir.

Regarding the departments where NSIs occurred, the proportion of HCV RNA-positive patients was higher in LDs than in non-LDs, and that of HCV RNA-negative patients was higher in non-LDs than in LDs in both eras (Table 2). Particularly, the proportion of HCV RNApositive patients was significantly lower in the era of IFN-free DAAs than in the era before DAAs in non-LDs

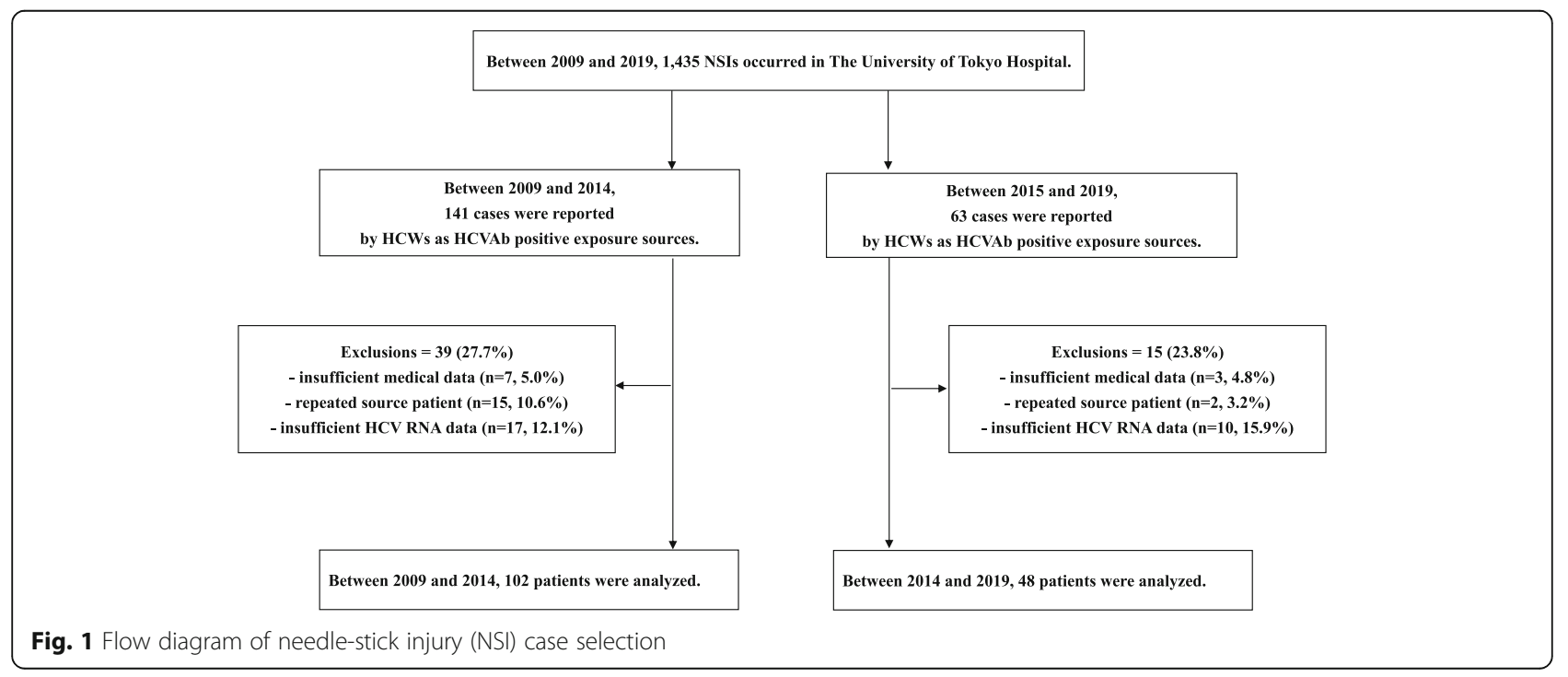


Table 1 Background characteristics of the HCV-Ab-positive patients

\begin{tabular}{lllll}
\hline Variables & $\begin{array}{l}\text { Entire period } \\
(\boldsymbol{n}=\mathbf{1 5 0 )}\end{array}$ & $\begin{array}{l}\text { Between 2009 and 2014 } \\
(\boldsymbol{n}=\mathbf{1 0 2})\end{array}$ & $\begin{array}{l}\text { Between 2015 and 2019 } \\
(\boldsymbol{n}=\mathbf{4 8})\end{array}$ & $\boldsymbol{p}$-value \\
\hline Age (years) & $70.0 \pm 11.8$ & $69.9 \pm 12.1$ & $70.4 \pm 11.4$ & 0.9229 \\
HCV RNA, positive - no. $(\%, 95 \mathrm{Cl})$ & $101(67.3,59.5-74.3)$ & $78(76.5,67.4-83.6)$ & $23(47.9,34.5-61.7)$ & $0.0007^{*}$ \\
Gender, male - no. $(\%, 95 \mathrm{Cl})$ & $88(58.7,50.7-66.2)$ & $61(59.8,50.1-68.8)$ & $27(56.3,42.3-69.3)$ & 0.7241 \\
Department, LDs - no. $(\%, 95 \mathrm{Cl})$ & $75(50.0,42.1-57.9)$ & $54(52.9,43.3-62.3)$ & $21(43.8,30.7-57.7)$ & 0.3816 \\
\hline
\end{tabular}

Values are expressed as means \pm SD unless otherwise stated

$H C V$ hepatitis $C$ virus, LDs liver disease-related departments, $C l$ confidence interval ${ }^{*} p<0.05$

(from $66.7 \%$ in the era before DAAs to $33.3 \%$ in the era of IFN-free DAAs, $p=0.0078$, Table 3 ).

\section{Discussion}

In this study, the overall incidence of NSIs in our hospital was lower in the era of IFN-free DAAs than in the era before IFN-free DAAs. Continuous and accumulating education to prevent the iatrogenic infection for HCWs, including the recommendation to use safety equipment, started from 2000's in our hospital, might contribute to the decrease in NSI cases.

Remarkable advances have been made in the treatment of chronic hepatitis $C$, as DAAs can efficiently eliminate HCV and patients can easily achieve an SVR [17]. We speculated that the rate of $\mathrm{HCV}$-infected source patients in the era of IFN-free DAAs would be lower than that in the era before IFN-free DAAs. As expected, the proportion of HCV RNA-positive patients significantly changed from 2009 through 2019, and a significant difference was observed between the eras before and after DAAs.

To assess the impact of antiviral treatments, including IFNs and DAAs, we further analyzed the antiviral HCV treatment histories in the source patients. As expected, in the era of IFN-free DAAs, HCV RNA-negative patients had a significantly higher frequency of DAA treatment history than HCV RNA-positive patients. IFNbased therapies were also administered in HCV RNAnegative patients as well as in HCV RNA-positive patients in both the eras before and of IFN-free DAAs. Considering these results, we assume that IFN-free DAAs might have contributed to the increase in NSIs associated with HCV RNA-negative source patients between 2015 and 2019.

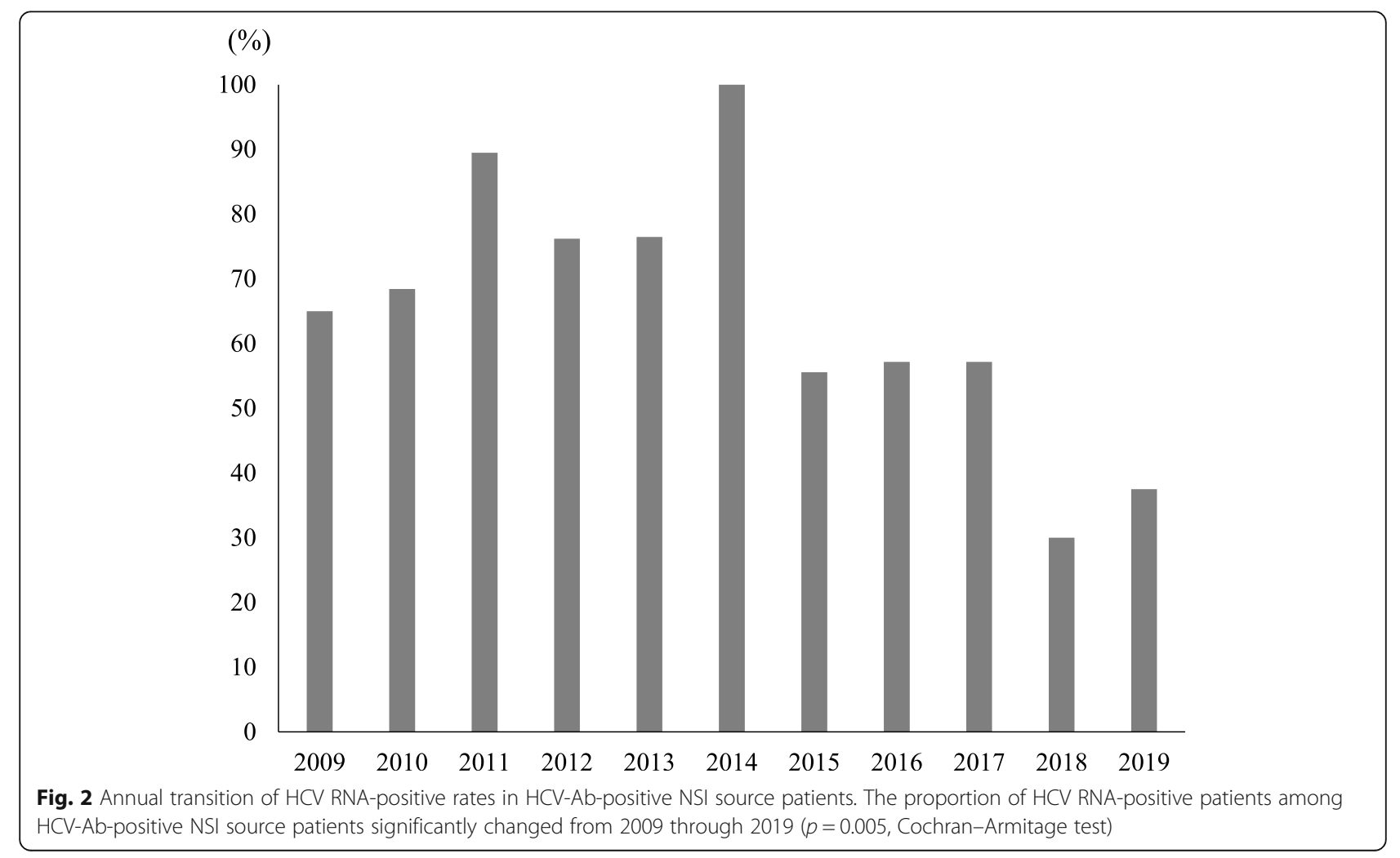


Table 2 Background characteristics according to HCV RNA positivity

\begin{tabular}{|c|c|c|c|c|c|c|}
\hline \multirow[t]{2}{*}{ Variables } & \multicolumn{3}{|c|}{$\begin{array}{l}\text { Between } 2009 \text { and } 2014 \\
(n=102)\end{array}$} & \multicolumn{3}{|c|}{$\begin{array}{l}\text { Between } 2015 \text { and } 2019 \\
(n=48)\end{array}$} \\
\hline & $\begin{array}{l}\text { HCV-RNA } \\
\text { Positive } \\
(n=78)\end{array}$ & $\begin{array}{l}\text { HCV-RNA } \\
\text { Negative } \\
(n=24)\end{array}$ & $p$-value & $\begin{array}{l}\text { HCV-RNA } \\
\text { Positive } \\
(n=23)\end{array}$ & $\begin{array}{l}\text { HCV-RNA } \\
\text { Negative } \\
(n=25)\end{array}$ & $p$-value \\
\hline Age (years) & $71.7 \pm 10.6$ & $63.8 \pm 14.5$ & $0.0122^{*}$ & $71.4 \pm 8.8$ & $69.4 \pm 13.5$ & 0.8123 \\
\hline Gender, male - no. $(\%, 95 \mathrm{Cl})$ & $44(56.4,45.4-66.9)$ & $17(70.8,50.8-85.1)$ & 0.2412 & $11(47.8,29.2-67.0)$ & $16(64.0,44.5-79.8)$ & 0.3830 \\
\hline HCV-Ab titer ${ }^{a}$ & $9.8 \pm 0.6$ & $6.9 \pm 2.9$ & $<0.0001^{*}$ & $10.0 \pm 0.1$ & $7.3 \pm 3.4$ & $0.0006^{*}$ \\
\hline Department, LDs - no. $(\%, 95 \mathrm{Cl})$ & $46(59.0,47.9-69.2)$ & $8(33.3,18.0-53.3)$ & $0.0358^{*}$ & $14(60.9,40.8-77.8)$ & $7(28.0,14.3-47.6)$ & $0.0405^{*}$ \\
\hline \multicolumn{7}{|l|}{ Antiviral therapy ${ }^{b}$} \\
\hline -Interferon, Yes - no. $(\%, 95 \mathrm{Cl})$ & $\begin{array}{l}27 \text { in } 75 \\
(36.0,26.1-47.3)\end{array}$ & $\begin{array}{l}12 \text { in } 21 \\
(57.1,36.5-75.5)\end{array}$ & 0.1302 & $\begin{array}{l}7 \text { in } 22 \\
(31.8,16.4-52.7)\end{array}$ & $\begin{array}{l}10 \text { in } 23 \\
(43.5,25.6-63.2)\end{array}$ & 0.5420 \\
\hline -DAAs, Yes - no. $(\%, 95 \mathrm{Cl})$ & - & - & - & $\begin{array}{l}2 \text { in } 22 \\
(9.1,2.5-27.8)\end{array}$ & $\begin{array}{l}9 \text { in } 23 \\
(39.1,22.2-59.2)\end{array}$ & $0.0351^{*}$ \\
\hline
\end{tabular}

Values are expressed as means \pm SD unless otherwise stated

$H C V$ hepatitis $C$ virus, $L D$ s liver disease-related departments, $C l$ confidence interval

${ }^{a}$ About HCV-Ab titer, between 2009 and 2014, 1 HCV RNA-negative patient had no result documented in the medical record

${ }^{b}$ About histories of antiviral therapy, between 2009 and 2014, 3 HCV RNA-positive and HCV RNA-negative patients each had no treatment history documented in the medical record. Between 2015 and 2019, 1 HCV RNA-positive and 2 HCV RNA-negative patients had no treatment history documented in their medical record. In the era after DAAs, 2 HCV RNA-positive and HCV RNA-negative patients each were treated with both IFN-based therapies and DAAs. Total number of each column was provided if there was missing data ${ }^{*} p<0.05$

Regarding the departments where NSIs occurred, the proportion of HCV RNA-positive patients was higher in LDs, and that of HCV RNA-negative patients was higher in non-LDs both in the eras before and after DAAs. These results were reasonable considering the patients' backgrounds. Namely, patients with active liver disorders, such as hepatitis $\mathrm{C}$, liver cirrhosis, and hepatocellular carcinoma, were treated in LDs. In particular, the proportion of HCV RNA-positive patients was significantly decreased in the era of IFN-free DAAs compared with the era before DAAs in the non-LD group. We recommend that $\mathrm{HCV}$ RNA should be analyzed when HCWs detect HCV-Ab positivity in patients, particularly those treated in nonLDs; this might lead to adequate risk assessment and a reduction in the mental burdens of HCWs. The HCV-Ab titer in a patient might support the estimation of $\mathrm{HCV}$ RNA positivity. It was reported that $\mathrm{HCV}-\mathrm{Ab}$ was still positive but its titer was continuously getting decreased for long duration after the achievement of SVR in HCV infected patients $[18,19]$. Actually, in this study, the titers of HCV-Ab in HCV RNA-positive patients were approximately 10 and over, whereas those in HCV RNA-negative patients were significantly lower than 10 . Therefore, HCV RNA negativity should be confirmed, especially in patients with relatively low HCV-Ab titers.

We must acknowledge some limitations of this study. First, this was a single-center cross-sectional study, and the findings need to be validated in other populations. In this study, we analyzed the specific population such as source patients of NSIs in a tertiary care hospital in Japan. Actually, HCV-Ab positive rates were different among the general population in Japan $(0.63 \%)$ [13], all of the patients whose serum HCV-Ab was examined in our hospital in the same period with this study $(3.4 \%$, 11,181 in 329,390 samples), and the source patients of NSIs in this study $(14.2 \%, 204$ in 1435 NSIs), chiefly due to the differences in the background of the analyzed subjects. However, to the best of our knowledge, there was

Table 3 Background characteristics according to department where NSIs occurred

\begin{tabular}{|c|c|c|c|c|c|c|}
\hline \multirow[t]{2}{*}{ Variables } & \multicolumn{3}{|c|}{$\begin{array}{l}\text { Liver disease-related departments } \\
(n=75)\end{array}$} & \multicolumn{3}{|c|}{$\begin{array}{l}\text { Nonliver disease-related departments } \\
(n=75)\end{array}$} \\
\hline & $\begin{array}{l}\text { Between } 2009 \text { and } \\
2014 \\
(n=54)\end{array}$ & $\begin{array}{l}\text { Between } 2015 \text { and } \\
2019 \\
(n=21)\end{array}$ & $p$-value & $\begin{array}{l}\text { Between } 2009 \text { and } \\
2014 \\
(n=48)\end{array}$ & $\begin{array}{l}\text { Between } 2015 \text { and } \\
2019 \\
(n=27)\end{array}$ & $p$-value \\
\hline Age (years) & $70.3 \pm 11.6$ & $71.3 \pm 9.2$ & 0.9812 & $69.3 \pm 12.7$ & $69.7 \pm 13.0$ & 0.8424 \\
\hline Gender, male - no. $(\%, 95 \mathrm{Cl})$ & $35(64.8,51.5-76.2)$ & $12(57.1,36.5-75.5)$ & 0.5998 & $26(54.2,40.3-67.4)$ & $15(55.6,37.3-72.4)$ & 1.0000 \\
\hline $\begin{array}{l}\text { HCV RNA, positive - no. }(\%, \\
95 \mathrm{Cl})\end{array}$ & $46(85.2,73.4-92.3)$ & $14(66.7,45.4-82.8)$ & 0.1064 & $32(66.7,52.5-78.3)$ & $9(33.3,18.6-52.2)$ & $0.0078^{*}$ \\
\hline
\end{tabular}

Values are expressed as means \pm SD unless otherwise stated $\mathrm{HCV}$ hepatitis $\mathrm{C}$ virus, $\mathrm{Cl}$ confidence interval

${ }^{*} p<0.05$ 
no study reporting the change in the actual HCV RNA positivity rate among $\mathrm{HCV}$-Ab-positive source patients of NSIs between the eras before and after the emergence of IFN-free DAAs. In addition, the hospital in this study is one of the largest hospitals in Japan. Considering these points, the data derived in this study are vital for understanding the current situation of and planning strategies to manage NSIs. Second, some cases might have been excluded due to a lack of HCV RNA data, despite HCV RNA positivity. As a result, it is possible that we slightly underestimated the actual rate of $\mathrm{HCV}$ infection. However, the rate of actual HCV infection among HCV-Abpositive cases in the era before IFN-free DAAs in this study (76.5\%; 95\% CI, 67.4 to $83.6 \%$ ) did not differ from the rate obtained from the anti-HCV-positive population-based cohort further confirmed with a recombinant immunoblot assay for HCV in the National Health and Nutrition Examination Study during a similar period between 2007 and 2012 (77.7\%; 95\% CI, 72.4 to $82.2 \%)$ [10]. These results were tended to be lower than those obtained in Japan in 1992 (89.0\%; 95\% CI, 80.9 to $93.9 \%$ ) [12]. It would be better to refer to results obtained in the era of IFN-free DAAs in Japan; however, to the best of our knowledge, no current reports exist. Notably, Japan was the first country to introduce IFNfree DAA regimens for HCV therapy. This is the first report describing changes in the $\mathrm{HCV}$ burden, with a focus on NSIs occurring before and after the DAA era in a hospital setting.

\section{Conclusions}

Actual HCV RNA positivity in NSI source patients decreased after the emergence of DAAs. DAAs might have contributed to this reduction, and HCV RNA-negative patients were predominant in non-LDs in the era of IFN-free DAAs. HCV RNA should be analyzed when HCWs detect HCV-Ab positivity in hospital patients.

\section{Abbreviations \\ HCW: Healthcare worker; NSI: Needle-stick injury; HCV: Hepatitis C virus; HBV: Hepatitis B virus; HIV: Human immunodeficiency virus; PEP: Postexposure prophylaxis; DAAs: Direct-acting antivirals; HCV-Ab: HCV antibody; IFN: Interferon; SVR: Sustained virological response; DCV/ ASV: Daclatasvir hydrochloride and asunaprevir; LDV/SOF: Ledipasvir/ sofosbuvir; SOF/RBV: Sofosbuvir/ribavirin; LD: Liver disease-related depart- ment; Non-LD: Nonliver disease-related department}

\section{Supplementary Information}

The online version contains supplementary material available at https://doi. org/10.1186/s12879-021-06117-4.

Additional file 1: Table S1. The number of NSIs in each year.

\section{Acknowledgments}

We thank Ms. Tamami Mahira, Ms. Yoshino Mitsuhashi, Mr. Akihiro Hirano, and Mr. Kazuaki Nishida (Infection Control Team, The University of Tokyo
Hospital) for their support in routine clinical practice in relation to infection control.

\section{Authors' contributions}

K Okushin, RS, TT, and K Okamoto contributed to the study concept and design; data acquisition, analysis, and interpretation; and drafting of the manuscript. KI, AK, CM, YK, NS, MI, SH, KE, HF, and $\mathrm{HY}$ participated in critical revision of the manuscript to ensure that the intellectual content was of a high standard. KK and KM helped with the study concept and design, data analysis and interpretation, drafting and critical revision of the manuscript, and study supervision. We confirm that all authors have reviewed and approved the final version of the manuscript.

\section{Funding}

This independent research was supported by AMED under Grant Number JP20fk0210040 (to KK) and JSPS KAKENHI Grant Number JP20K17014 (to Kazuya Okushin). No additional external funding was received. The funders played no role in the study design, data collection or analysis, decision to publish, or manuscript preparation.

Availability of data and materials

All data generated or analyzed during this study are included in this published article.

\section{Declarations}

Ethics approval and consent to participate

This study was approved by the Ethics Committee of The University of Tokyo (No. 2187) and conformed to the Declaration of Helsinki. Informed consent was obtained from all subjects included in this study. Informed consent was obtained from all subjects included in this study using the opt-out informed consent procedure. Namely, on admission, all of the inpatients were provided with a document explaining the policy of The University of Tokyo Hospital on protection of personal information and handling of samples of human origin. Any patients could request for suspension of use, elimination, provision of own personal information. In addition, a document that declares an opt-out policy by which any possible patient could refuse to be included in this study was uploaded on the web page of the The University of Tokyo Hospital.

\section{Consent for publication}

Not applicable.

\section{Competing interests}

No author has any conflict of interest.

\section{Author details}

${ }^{1}$ Department of Infection Control and Prevention, Graduate School of Medicine, The University of Tokyo, 7-3-1 Hongo, Bunkyo-ku, Tokyo 113-8655, Japan. ${ }^{2}$ Department of Gastroenterology, Graduate School of Medicine, The University of Tokyo, Tokyo, Japan. ${ }^{3}$ Division of Infectious Diseases, Advanced Clinical Research Center, The Institute of Medical Science, The University of Tokyo, Tokyo, Japan. ${ }^{4}$ Department of Infectious Diseases, Graduate School of Medicine, The University of Tokyo, Tokyo, Japan.

Received: 28 January 2021 Accepted: 23 April 2021

Published online: 30 April 2021

\section{References}

1. Pruss-Ustun A, Rapiti E, Hutin Y. Estimation of the global burden of disease attributable to contaminated sharps injuries among health-care workers. Am J Ind Med. 2005;48(6):482-90. https://doi.org/10.1002/ajim.20230.

2. Panlilio AL, Orelien JG, Srivastava PU, Jagger J, Cohn RD, Cardo DM. Estimate of the annual number of percutaneous injuries among hospitalbased healthcare workers in the United States, 1997-1998. Infect Control Hosp Epidemiol. 2004;25(7):556-62. https://doi.org/10.1086/502439.

3. Kuhar DT, Henderson DK, Struble KA, Heneine W, Thomas V, Cheever LW, et al. Updated US public health service guidelines for the management of occupational exposures to human immunodeficiency virus and recommendations for postexposure prophylaxis. Infect Control Hosp Epidemiol. 2013;34(9):875-92. https://doi.org/10.1086/672271. 
4. Schillie S, Murphy TV, Sawyer M, Ly K, Hughes E, Jiles R, et al. CDC guidance for evaluating health-care personnel for hepatitis $B$ virus protection and for administering postexposure management. MMWR Recommend Rep. 62(RR10):1-19.

5. Freeman ZT, Cox AL. Lessons from nature: understanding immunity to HCV to guide vaccine design. PLoS Pathog. 2016;12(6):e1005632. https://doi. org/10.1371/journal.ppat.1005632.

6. Naggie S, Holland DP, Sulkowski MS, Thomas DL. Hepatitis C virus Postexposure prophylaxis in the healthcare worker: why direct-acting antivirals Don't change a thing. Clin Infect Dis. 2017;64(1):92-9. https://doi. org/10.1093/cid/ciw656.

7. Service USPH. Updated U.S. Public Health Service Guidelines for the Management of Occupational Exposures to HBV, HCV, and HIV and Recommendations for Postexposure Prophylaxis. MMWR Recommend Rep. 2001:50(RR-11):1-52.

8. Tomkins SE, Elford J, Nichols T, Aston J, Cliffe SJ, Roy K, et al. Occupational transmission of hepatitis $C$ in healthcare workers and factors associated with seroconversion: UK surveillance data. J Viral Hepat. 2012;19(3):199-204. https://doi.org/10.1111/j.1365-2893.2011.01543.x.

9. Centers for Disease C, Prevention. Testing for HCV infection: an update of guidance for clinicians and laboratorians. MMWR Morb Mortal Wkly Rep. 2013;62(18):362-5.

10. Moorman AC, Drobenuic J, Kamili S. Prevalence of false-positive hepatitis $C$ antibody results, National Health and nutrition examination study (NHANES) 2007-2012. J Clin Virol. 2017;89:1-4. https://doi.org/10.1016/j.jcv.2017.01.007.

11. Yazdanpanah Y, De Carli G, Migueres B, Lot F, Campins M, Colombo C, et al. Risk factors for hepatitis $C$ virus transmission to health care workers after occupational exposure: a European case-control study. Clin Infect Dis. 2005; 41(10):1423-30. https://doi.org/10.1086/497131.

12. Mitsui T, Iwano K, Masuko K, Yamazaki C, Okamoto H, Tsuda F, et al. Hepatitis $\mathrm{C}$ virus infection in medical personnel after needlestick accident. Hepatology. 1992;16(5):1109-14.

13. Tanaka J, Koyama T, Mizui M, Uchida S, Katayama K, Matsuo J, et al. Total numbers of undiagnosed carriers of hepatitis $C$ and $B$ viruses in Japan estimated by age- and area-specific prevalence on the national scale. Intervirology. 2011;54(4):185-95. https://doi.org/10.1159/000324525.

14. Yatsuhashi H. Past, present, and future of viral hepatitis $\mathrm{C}$ in Japan. Euroasian J Hepatogastroenterol. 2016;6(1):49-51. https://doi.org/10.5005/jpjournals-10018-1166.

15. Kumada H, Suzuki Y, Ikeda K, Toyota J, Karino Y, Chayama K, et al. Daclatasvir plus asunaprevir for chronic HCV genotype 1b infection. Hepatology. 2014;59(6):2083-91.

16. Mizokami M, Yokosuka O, Takehara T, Sakamoto N, Korenaga M, Mochizuki $\mathrm{H}$, et al. Ledipasvir and sofosbuvir fixed-dose combination with and without ribavirin for 12 weeks in treatment-naive and previously treated Japanese patients with genotype 1 hepatitis C: an open-label, randomised, phase 3 trial. Lancet Infect Dis. 2015;15(6):645-53. https://doi.org/10.1016/S1473-3 099(15)70099-X

17. Baumert TF, Berg T, Lim JK, Nelson DR. Status of direct-acting antiviral therapy for hepatitis $C$ virus infection and remaining challenges. Gastroenterology. 2019;156(2):431-45. https://doi.org/10.1053/j.gastro.2018.1 0.024 .

18. Toyoda H, Kumada T, Kiriyama S, Sone Y, Tanikawa M, Hisanaga Y, et al. Changes in hepatitis $\mathrm{C}$ virus (HCV) antibody status in patients with chronic hepatitis $\mathrm{C}$ after eradication of HCV infection by interferon therapy. Clin Infect Dis. 2005;40(6):e49-54. https://doi.org/10.1086/428128.

19. Maylin S, Martinot-Peignoux M, Ripault MP, Moucari R, Cardoso AC, Boyer N, et al. Sustained virological response is associated with clearance of hepatitis C virus RNA and a decrease in hepatitis C virus antibody. Liver Int. 2009; 29(4):511-7. https://doi.org/10.1111/j.1478-3231.2008.01918.x.

\section{Publisher's Note}

Springer Nature remains neutral with regard to jurisdictional claims in published maps and institutional affiliations.

Ready to submit your research? Choose BMC and benefit from:

- fast, convenient online submission

- thorough peer review by experienced researchers in your field

- rapid publication on acceptance

- support for research data, including large and complex data types

- gold Open Access which fosters wider collaboration and increased citations

- maximum visibility for your research: over $100 \mathrm{M}$ website views per year

At BMC, research is always in progress.

Learn more biomedcentral.com/submissions 